\title{
Estimating population size of the red swamp crayfish (Procambarus clarkii) in fish-ponds (Brenne, Central France)
}

\author{
A. Coignet ${ }^{(1,2) \star}$, F. Pinet ${ }^{(2)}$, C. Souty-Grosset ${ }^{(1)}$
}

Received October 7, 2011

Revised June 1st, 2012

Accepted June 4, 2012

Key-words:

Procambarus

clarkii,

fish-ponds,

mark-recapture, population size estimation

\section{ABSTRACT}

The red swamp crayfish, Procambarus clarkii, was discovered in 2007 in the "Parc naturel régional (PNR) de la Brenne" (France). Ten colonized sites have been identified in the park to date, including two new sites discovered in 2011. The present study aims at establishing a protocol suitable for estimating the population size of $P$. clarkii by the use of a Capture-MarkRecapture (CMR) technique in a chain of five connected fish-ponds. Results show different cohorts of individuals among seasons and fish-ponds. However, trapping effort was not efficient enough to obtain an accurate estimate of the population size of this species in a fish-pond larger than 2-3 ha. On the other hand, the adopted protocol appeared useful to assess, in smaller fish-ponds, the effect of intensive trapping and other control methods on $P$. clarkii populations.

\section{RÉSUMÉ}

Estimation de la taille de populations d'écrevisse de Louisiane (Procambarus clarkii) dans des étangs de pisciculture (Brenne, Central France)

Mots-clés :

Procambarus

clarkii, étangs, marquagerecapture, taille de la population
L'écrevisse de Louisiane, Procambarus clarkii, a été récemment découverte (2007) dans le "Parc naturel régional (PNR) de la Brenne" (France). Dix foyers d'infestation sont à présent identifiés dans le parc, dont deux très récemment (2011). La présente étude a pour but d'établir un protocole efficace pour estimer la taille des populations de $P$. clarkii par la technique de Capture-Marquage-Recapture (CMR), au niveau de 5 étangs piscicoles organisés en chaine. Les résultats montrent différentes cohortes d'individus variant selon les saisons et selon les étangs. L'effort de piégeage effectué dans cette étude s'avère insuffisant pour des étangs supérieurs à 2 ou 3 ha. Pour les étangs de plus petite taille, un tel protocole semble être plus adapté et permettrait d'évaluer l'impact du piégeage intensif et autres méthodes de contrôle sur les populations de P. clarkii.

\section{INTRODUCTION}

According to Strayer (2010), the strong ecological effects of freshwater alien species can be divided among five different groups: consumers, fishes, aquatic plants, diseases,

(1) Université de Poitiers, Laboratoire Écologie \& Biologie des Interactions, Équipe Écologie Évolution Symbiose, UMR CNRS 7267, 40 avenue du Recteur Pineau, 86022 Poitiers Cedex, France

(2) Parc naturel régional de la Brenne, Maison du Parc - Le Bouchet, 36300 Rosnay, France

^ Corresponding author: a.coignet@parc-naturel-brenne.fr 
and decapods that act as powerful omnivores. Indeed most invasive decapods are nonindigenous crayfish species (NICS), which often have strong direct and indirect ecological negative impacts, on the food web of many ecosystems (Lodge et al., 2000). Native to north-eastern Mexico and south-central USA (Hobbs, 1989), the red swamp crayfish Procambarus clarkii is now widespread and abundant across the world (Gherardi, 2006). After having been introduced for the first time in 1973 into a European country (southern Spain) (Habsburgo-Lorena, 1979), this NICS is currently present in 15 European countries (Holdich et al., 2009).

Most $P$. clarkii's populations are present in Spain, Italy and France. In France, the first population was recorded in 1988 in Charente-Maritime department, since then, it has spread through most of the hydrographic basins of this department. The strongest geographical expansion of $P$. clarkii occurred in the period 2001-2006 (Collas et al., 2007). Everywhere, this NICS appears to be a very strong competitor with the native crayfish, being highly aggressive and generally resistant to diseases, with some exceptions (Edgerton et al., 2004). Procambarus clarkii can withstand extreme environmental conditions (review in Gherardi, 2007) and is able to colonize varied ecosystems. It is continuously in the process of colonizing new departments, new watersheds, and of eliminating indigenous crayfish species (ICS) and other species of conservation concern. Due to its invasive potential, $P$. clarkii is now present in 61 departments of metropolitan France (Collas et al., 2007).

Impacts of its proliferation are catastrophic for the invaded ecosystems. Geiger et al. (2005) have synthesized evidence of the ecological impacts the species has on the trophic food webs of Mediterranean wetlands, and how it changed their structure and functioning. Its success as an invader is facilitated by high reproductive output, short development time, and a flexible feeding strategy. As a consequence of its omnivorous feeding habit, it affects both lower and higher trophic levels, by grazing on macrophytes and preying on macroinvertebrates, and has a role as an important food source for several vertebrate species. In addition to being a vector of the crayfish plague, due to its short life-history, rapid growth, burrowing activities and high population density, it can adversely impact the aquatic environment (Rodriguez et al., 2003, 2005; Gherardi, 2006; Gherardi and Acquistapace, 2007; Souty-Grosset, 2009).

Identified for the first time in 2007 in the "Parc naturel régional de la Brenne" (Central France), $P$. clarkii has very quickly caused severe problems. It has colonized various environments and dug burrows in the banks of ponds, particularly fish-ponds. This resulted in biological imbalances for the affected ecosystem and difficulties to control populations. To date ten infestation sites have been identified, including two discovered very recently (in 2011). Many trapping campaigns of $P$. clarkii are planned by both park officers and owners of fish-ponds. However, to be able to assess the effects of control methods on populations of this species, it is first necessary to define the appropriate technique for estimating the population size of $P$. clarkii in fish-ponds of different sizes and at different seasons.

While many studies have been conducted to obtain an estimate of animal abundance, such as amphibians (Pellet and Pellet, 2003) and reptiles (Koller and Ursenbacher, 1996), estimating the population size of decapod crustaceans, particularly crayfish, remains very difficult to undertake and produce reliable mixed results, depending on the crayfish species and habitats. There are many descriptions of monitoring methods in the literature - perhaps because each biotope appears unique and demands a different methodology (Somers and Stechey, 1986). However, the Capture-Mark-Recapture (CMR) method has been efficient for estimating the population size of crayfish (see the review of Nowicki et al., 2008). Acosta and Perry (2000) used CMR techniques for monitoring the density of Procambarus alleni in Florida Everglades and demonstrated the efficacy of this technique for sampling crayfish populations in flooded marsh habitats. Da Silva and Bueno (2005) estimated the size of an established population of $P$. clarkii in an artificial pond in São Paulo, Brazil, by the means of CMR techniques and applied the Schumacher and Eschmeyer's method for population size determination (Krebs, 1999). They showed that estimates should be performed over no longer than three weeks. This not only seems to be a fairly adequate time period for estimating the population size of a 


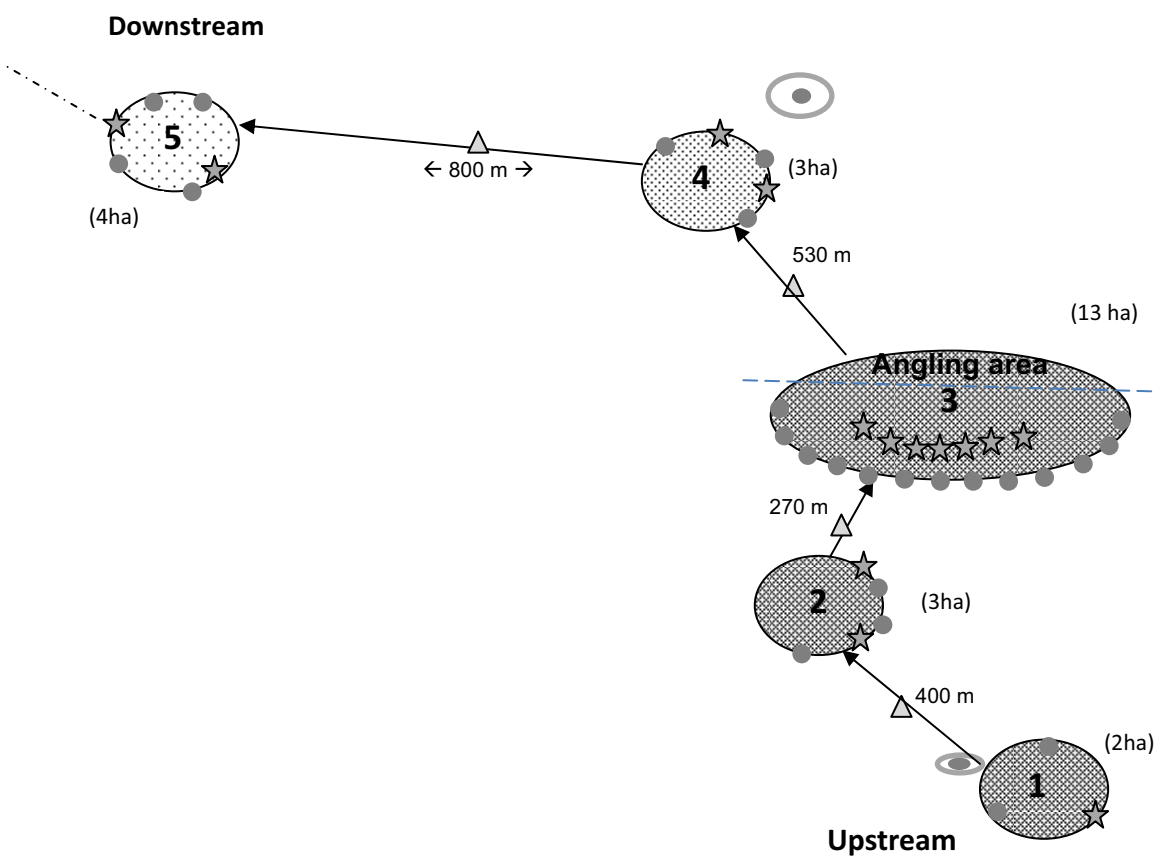

\section{Figure 1}

Chain of fish-ponds, with presence/absence of P. clarkii. Fish-ponds are represented with $\bigcirc$, the ponds with $\bigcirc$, the traps between two fish-ponds with $\triangle$, traps for the session 1 (March) with $\bigcirc$ and additional traps for the sessions 2 and 3 (April and June-July) with $\hat{\boldsymbol{W}}$. Represents fish-pond with crayfish, (1) fish-pond with few crayfish and $\bigcirc$ without crayfish.

closed population of crayfish but would also guarantee that, even if one or more specimens molted, ecdysis would not likely occur twice for the same adult during this short three-week period. These methods were also applied to indigenous crayfish (Astacus astacus) (Maguire et al., 2004).

The aim of the present study was to understand whether CMR techniques are effective in fish-ponds. We also conducted a study of $P$. clarkii population's characteristics with the aim of characterizing the different cohorts of individuals.

\section{MATERIALS AND METHODS}

\section{> STUDY AREA}

A chain of five linked fish-ponds located in the south of the Brenne Park offers an unusual opportunity to analyze the efficacy of CMR techniques (Figure 1). A fish-pond is an area of standing water, shallow (1.5 m on average), equipped with a floodgate. The smaller fish-ponds in Brenne cover 1-3 ha and the largest spread over 180 ha. Fish-ponds are emblematic of the Brenne, called "the land of thousand fish-ponds". There are over 4000 fish-ponds today. They are organized in chains; they empty into each other within the same watershed.

This chain studied here is 'simplified' as compared to other chains in the centre of the park where very numerous fish-ponds are linked. The five fish-ponds studied are all connected by ditches, which allow checking movements of crayfish between fish-ponds by placing traps between them. The three fish-ponds located furthest upstream in the chain (fish-pond 1 ( $2 \mathrm{ha}$ ), fish-pond 2 ( $3 \mathrm{ha}$ ) and fish-pond 3 (13 ha)) are affected by the presence of $P$. clarkii, whereas fish-pond 4 ( $3 \mathrm{ha}$ ) is in a very early stage of colonization and fish-pond 5 ( 4 ha) is unaffected until now (Figure 1). 


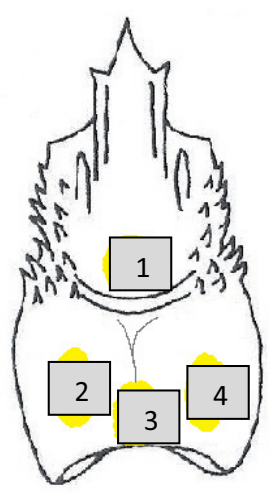

\begin{tabular}{|c|c|}
\hline 1 & Capture, 1st mark \\
\hline 2 & 1st recapture, 2nd mark \\
\hline 3 & 2nd recapture, 3rd mark \\
\hline 4 & 3rd recapture, 4th mark \\
\hline
\end{tabular}

\section{Figure 2}

Location of individual tags.

\section{> CRAYFISH TRAPPING AND CAPTURE-MARK-RECAPTURE (CMR)}

A total of 40 cylindrical traps with two entrances and a place to put bait (length: $65 \mathrm{~cm}$, diameter: $35 \mathrm{~cm}$, mesh size: $5 \mathrm{~mm}$ ), were positioned in fish-ponds and in their connecting ditches, as well as in nearby ponds. Bait consisted of pieces of carp. Traps were lifted after $24 \mathrm{~h}$, following Bellanger (2007). This relatively short period of trapping was necessary to avoid cannibalism, injuries and decreased numbers of trapped crayfish, due to competitive exclusion by dominant crayfish.

Water temperature was measured $10 \mathrm{~cm}$ below the surface during each field campaign. Field sessions began in March 2010 with 1 trap.ha ${ }^{-1}$. Trapping effort proved to be insufficient for a reliable estimate of population size, so the density of traps was increased to 1.5 traps.ha $^{-1}$ for sessions 2 and 3, in April and June-July 2010, respectively.

To assess the size of $P$. clarkii's population in each fish-pond, the CMR technique was chosen. Each caught crayfish was sexed, weighed and measured (total length, from the telson to the tip of the rostrum). The sex ratio is computed as number of males over the total number of individuals.

The first capture was followed by three recaptures over two weeks of experimentation. All individuals were marked with coloured varnish on the cephalothorax (Figure 2). Each fishpond corresponded to a different color varnish, which allowed us to recognize the fish-pond of provenance of each crayfish subsequently trapped, but not individually. CPUE (Catch Per Unit Effort) was calculated as the number of crayfish caught per trap within $24 \mathrm{~h}$.

The french law prohibits releasing the individuals in water, transporting them live or using them as bait. For scientific reasons in this study, caught individuals were not killed each time but exceptionally at the end of the last session, and not between sessions in order to work on the same population. However, eggs and larvae from berried females were removed before returning the female to the water.

\section{> DATA ANALYSIS}

Population size in each fish-pond was estimated using the program MARK (developed by White and Burnham in 1999: CA-Visual Objects 2.0 Standard Application) by creating a matrix of presence/absence in excel which was transferred to the software. The "closed captures" model was tested, as each population was assumed to be closed, i.e. crayfish were assumed not to migrate from one fish-pond to another. We also used the MARK software to test another model "Jolly-Seber" that, on the contrary, assumed an open population (Bourgault, 2008).

In order to compare different methods of estimating numbers of individuals, we used paired Student's $t$-tests to compare estimates from one session to another and population models (open or closed population). When the data were not normally distributed or when the 
Table I

Estimates of population size, first period (18 to 30 March 2010) with a trap density of 1 ha $^{-1}$.

\begin{tabular}{|l|c|c|c|c|c|}
\hline Fish-ponds & $\begin{array}{c}\text { MARK software } \\
\text { Population } \\
\text { estimate }(\mathrm{Nt}) \\
\text { closed captures }\end{array}$ & $\begin{array}{c}\text { SE } \\
\text { (standard } \\
\text { error) }\end{array}$ & $\begin{array}{c}\mathrm{Cl} \\
\text { (confidence } \\
\text { interval 95\%) }\end{array}$ & $\begin{array}{c}\mathrm{CV} \\
\text { (coefficient } \\
\text { variation \%) }\end{array}$ & $\begin{array}{c}\text { Capture } \\
\text { probability } \mathrm{pC}(\%) \\
\text { Recapture } \\
\text { probability } p R(\%)\end{array}$ \\
\hline $\begin{array}{l}\text { Fish-pond 1 } \\
\text { (2 ha) }\end{array}$ & $\mathrm{Nt}=185$ & 40 & $130-292$ & 22 & $p C=12$ \\
\hline $\begin{array}{l}\text { Fish-pond 2 } \\
\text { (3 ha) }\end{array}$ & $N t=452$ & 54 & $377-597$ & 12 & $p C=23$ \\
\hline $\begin{array}{l}\text { Fish-pond 3 } \\
\text { (13 ha) }\end{array}$ & $N t=2569$ & 206 & $2209-3021$ & 8 & $p C=8$ \\
\hline
\end{tabular}

\section{Table II}

Estimates of population size, second period (19 to 28 April 2010) with a trap density of $1.5 \mathrm{ha}^{-1}$.

\begin{tabular}{|l|c|c|c|c|c|}
\hline Fish-ponds & $\begin{array}{c}\text { MARK software } \\
\text { Population } \\
\text { estimate (Nt) } \\
\text { closed captures }\end{array}$ & $\begin{array}{c}\text { SE } \\
\text { (standard } \\
\text { error) }\end{array}$ & $\begin{array}{c}\text { Cl } \\
\text { (confidence } \\
\text { interval 95\%) }\end{array}$ & $\begin{array}{c}\text { CV } \\
\text { (coefficient } \\
\text { variation \%) }\end{array}$ & $\begin{array}{c}\text { Capture } \\
\text { probability } \\
p C(\%)\end{array}$ \\
\hline $\begin{array}{l}\text { Fish-pond 1 } \\
\text { (2 ha) }\end{array}$ & $N t=253$ & 53 & $178-393$ & 21 & $p C=10$ \\
\hline $\begin{array}{l}\text { Fish-pond 2 } \\
\text { (3 ha) }\end{array}$ & $N t=828$ & 210 & $526-1379$ & 25 & $p C=5$ \\
\hline $\begin{array}{l}\text { Fish-pond 3 } \\
\text { (13 ha) }\end{array}$ & $N t=9488$ & 3505 & $4786-19265$ & 37 & $p C=1$ \\
\hline
\end{tabular}

\section{Table III}

Estimates of population size, third period (28 June to 9 July 2010) with a trap density of $1.5 \mathrm{ha}^{-1}$.

\begin{tabular}{|l|c|c|c|c|c|}
\hline Fish-ponds & $\begin{array}{c}\text { MARK software } \\
\text { Population } \\
\text { estimate }(N \text { t) } \\
\text { closed captures }\end{array}$ & $\begin{array}{c}\text { SE } \\
\text { (standard } \\
\text { error) }\end{array}$ & $\begin{array}{c}\text { Cl } \\
\text { (confidence } \\
\text { interval 95\%) }\end{array}$ & $\begin{array}{c}\text { CV } \\
\text { (coefficient } \\
\text { variation \%) }\end{array}$ & $\begin{array}{c}\text { Capture } \\
\text { probability } \\
p C(\%)\end{array}$ \\
\hline $\begin{array}{l}\text { Fish-pond 1 } \\
\text { (2 ha) }\end{array}$ & $N t=952$ & 37 & $885-1029$ & 4 & $p C=14$ \\
\hline $\begin{array}{l}\text { Fish-pond 2 } \\
\text { (3 ha) }\end{array}$ & $N t=3546$ & 298 & $3025-4197$ & 8 & $p C=7$ \\
\hline $\begin{array}{l}\text { Fish-pond 3 } \\
\text { (13 ha) }\end{array}$ & $N t=24611$ & 2330 & $20495-29669$ & 10 & $p C=7$ \\
\hline
\end{tabular}

variances were not homogeneous, the Wilcoxon test was applied using the software "R commander" (Version 1.4-5).

\section{RESULTS}

\section{> ESTIMATES OF POPULATION SIZE}

Tables I-III show the estimated size of $P$. clarkii's population obtained using the software MARK; estimates varied according to different field campaigns. Sessions 1 and 3 revealed the greatest numbers of trapped individuals, reflecting more pertinent results. The coefficient of variation $(\mathrm{CV})$ is an index of the accuracy of our estimates. When this ratio is between $0-15 \%$, the estimate $(N t)$ is reliable for the fraction of the population sampled. A capture probability $(\mathrm{pC})$ of $30 \%$ or more is also required to be considered a good estimate. In Tables I and III, the CV was lower for session 3 (4-10\%). For fish-pond 1, pC was constant. Fish-pond 
2 had a $p C$ of $23 \%$ in session 1 , but a recapture probability $(p R)$ less than $11 \%$, meaning that either an effect of traps occurs or our trapping effort is insufficient. For this reason, trapping effort was increased (to 1.5 traps $\cdot$ ha $^{-1}$ ) in sessions 2 and 3 . Nevertheless, the probabilities of catches were always low, with a $p C$ of only $1 \%$ in session 2 (fish-pond 3 ) and $7 \%$ in session 3 . Concerning fish-pond 4 , only one individual was captured during the sessions, so no estimate was calculated. No crayfish were caught in fish-pond 5.

Estimates obtained with open and closed models did not differ significantly (Student's $t$-test, session 1: $p=0.66$, session $2: p=0.44$, session $3: p=0.25$ ).

\section{> COHORTS OF INDIVIDUALS AND SEX-RATIO}

The three sessions differed for the groups of individuals, sex ratios and, in some cases, between sites (Tables IV-VI).

Sex ratio was biased towards males in one site and biased towards females in another site in the same session (Tables IV-VI), for example between fish-ponds 1 and 2 . Figures 3-5 show cohorts of individuals caught during the 3 sessions for the fish-pond 3 . Fourteen $\%$ of berried females were captured in session $1 \mathrm{vs}$. $3 \%$ captured in session 2 and $0 \%$ in session 3 . The sex ratio was also different, being in favor of females in session 1 but in favor of males in the other sessions. Besides, the number of individuals caught differed between sessions.

Despite the increased trapping effort in sessions 2 and 3, only 37 individuals were captured during the first capture in the second session, against 234 in session 1 and 680 individuals in session 3 (Figures 3-5). Equivalent differences were also observed in fish-ponds 1 and 2.

\section{> CATCH PER UNIT EFFORT (CPUE)}

CPUE gives an average number of individuals per trap during each session. The fluctuations in the average number of individuals per trap followed seasonal variations (Figure 6), ranging from 17.5 individuals in March to 5.5 individuals in April and 32.7 individuals in June in fishpond 3. A decreased CPUE was observed in each fish-pond in April, despite the rise in surface water temperatures.

\section{> TOTAL CRAYFISH-CATCHES}

A total of 706 crayfish were captured in fish-pond 1, 1572 in fish-pond 2, 3916 in fish-pond 3 and only 1 in the fish-pond 4, totaling 6194 P. clarkii captured in the chain of fish-ponds during the three sessions (Tables IV-VI). The sex ratio was $51.3 \%$ of males and females comprising $1.1 \%$ of berried female.

Mean body length (rostrum-telson) of captured individuals was $10.5 \mathrm{~cm}$ for a mean body weight of $33.15 \mathrm{~g}$. The smallest individual captured measured $5 \mathrm{~cm}$ and weighed $3 \mathrm{~g}$ (fishpond 2 in July, session 3). The largest individual was $14.9 \mathrm{~cm}$ long, the heaviest weighed $106 \mathrm{~g}$ (fish-pond 3 in March, session 2).

The number of eggs per berried female averaged 90, with a maximum of 339 eggs (session 1 , fish-pond 3).

\section{DISCUSSION}

Baited traps and mark-recapture techniques are commonly used to estimate the population size of crayfish, excluding juveniles, which cannot be captured due to the large mesh size (Maguire et al., 2004); indeed, we caught only crayfish larger than $5 \mathrm{~cm}$. The marking technique that we adopted was suitable to have an estimate during a short period (to avoid loss of marks). Similar techniques have been used in other studies on the same species, as in Brazil 
A. Coignet et al.: Knowl. Managt. Aquatic Ecosyst. (2012) 406, 02
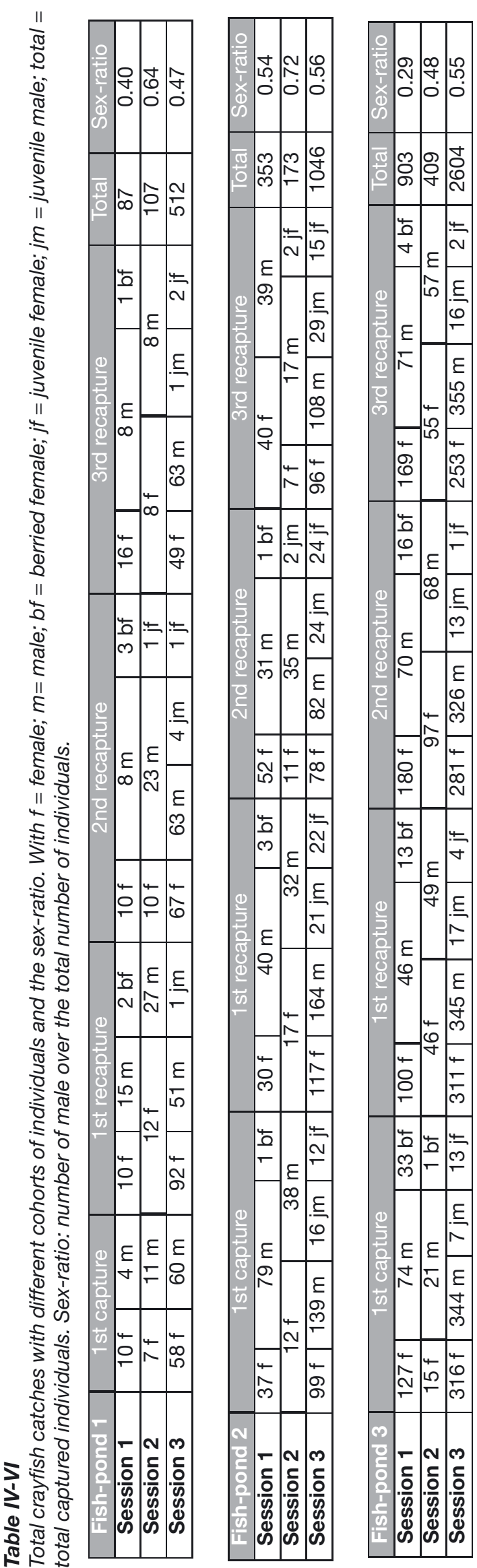


\section{Number of crayfish}

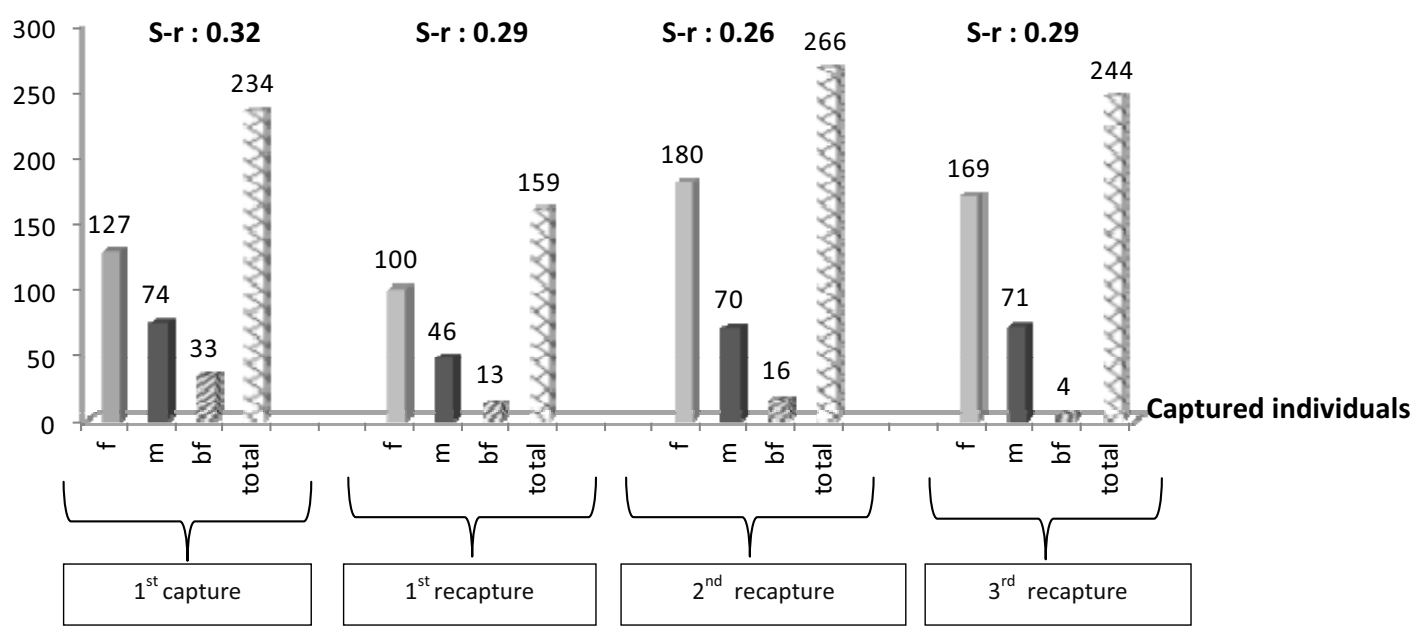

Figure 3

Trapped crayfish during the first session in the fish-pond 3. Cohorts of individuals and sex-ratio S-r: number of male over the total number ofindividuals. $f=$ female; $m=$ male; $b f=$ berried female; total $=$ total caught individuals.

\section{Number of crayfish}

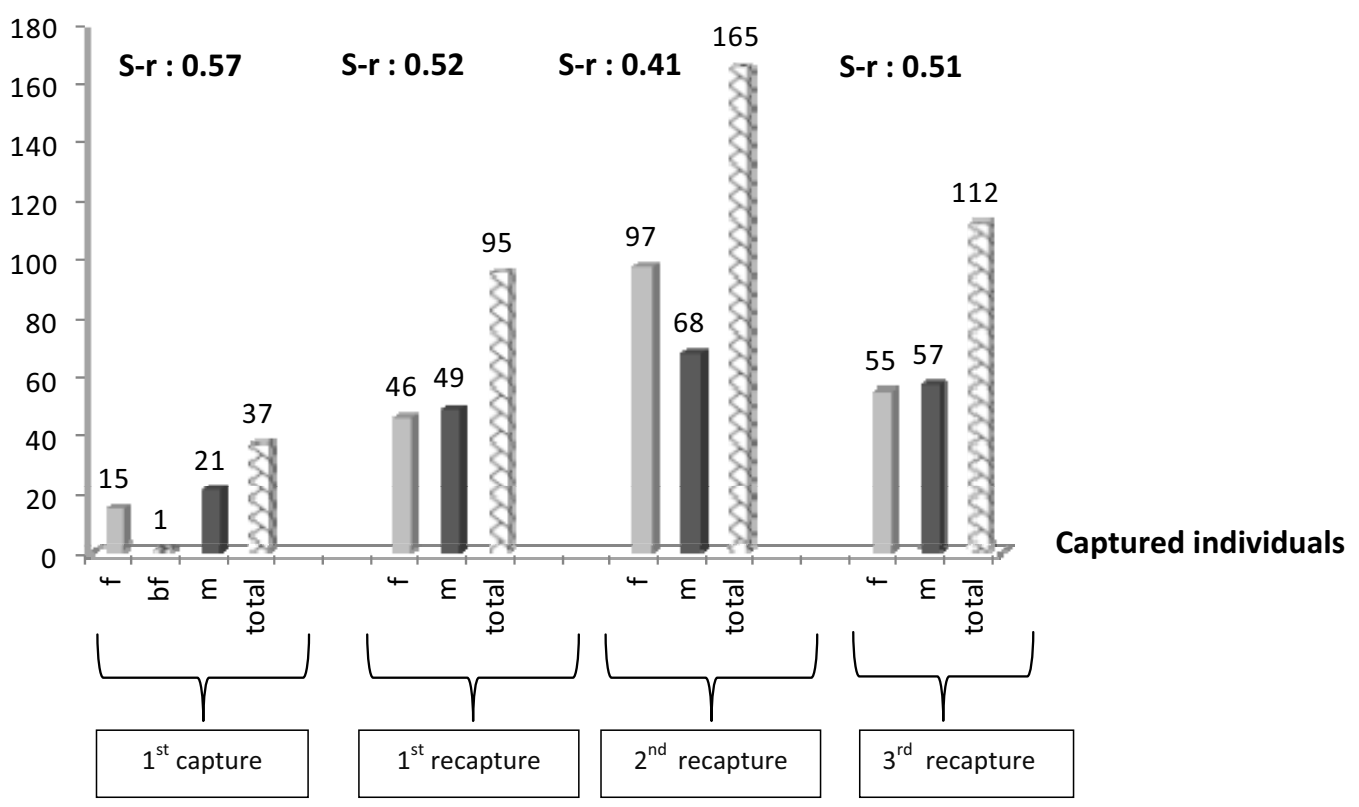

Figure 4

Individuals caught during the second period in the fish-pond 3 , and the sex ratio.

by Da Silva and Bueno (2005). The estimate we obtained shows changes between sessions, which may suggest the intervention of a seasonal effect in the population size. It would be preferable to conduct trapping in late winter (with rising temperatures) and summer (with high temperatures) to possibly detect periods of increased activity of crayfish. Also, during the 3rd session marked crayfish were captured in the ditches between fish-ponds, which indicated that crayfish can migrate from one fish-pond to another, at least during June-July. This proves that it is important to control the whole chain. Session 2 appeared to be not useful 8 in this study, because of the low numbers of individuals caught compared to the two other 


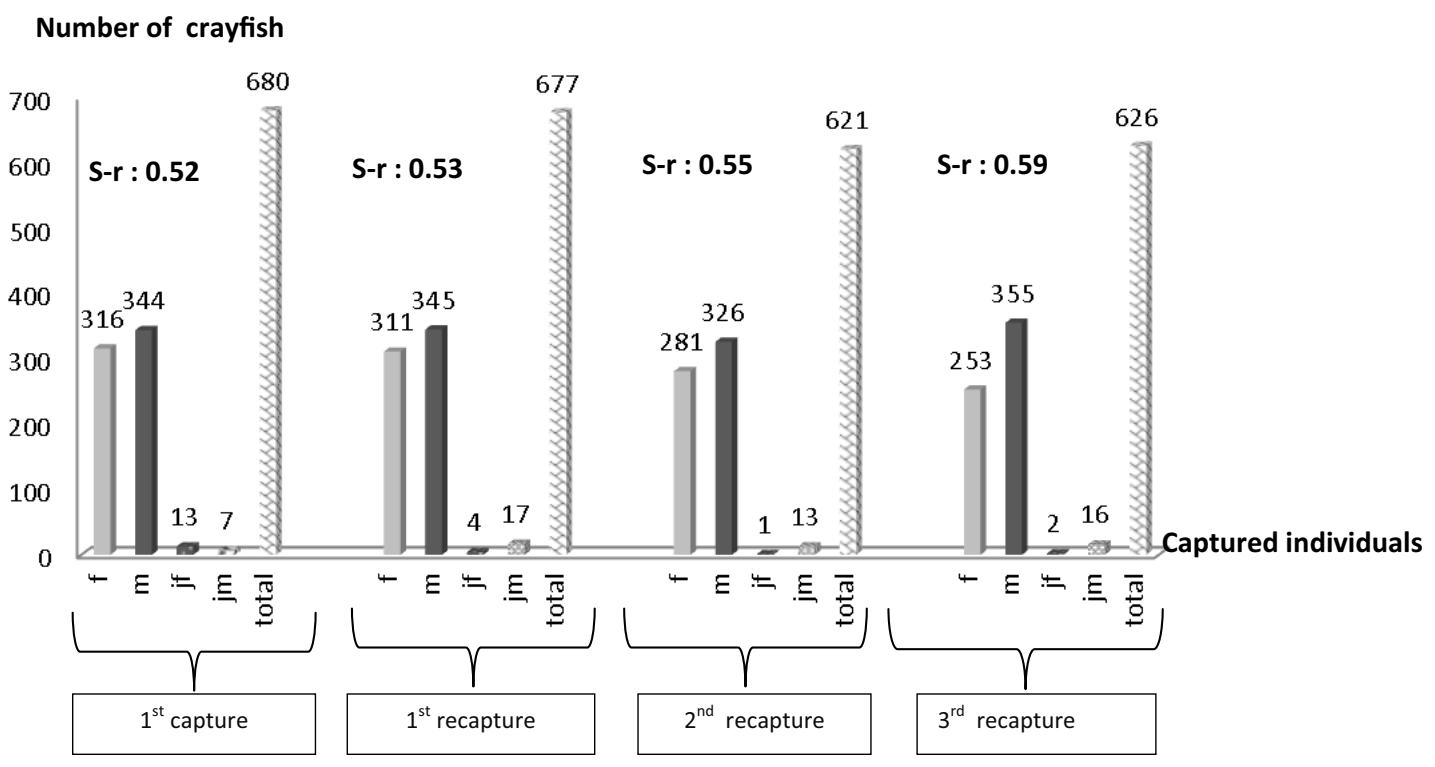

\section{Figure 5}

Individuals caught during the third session in the fish-pond 3. With the same legend and jf $=$ juvenile female; jm = juvenile male.

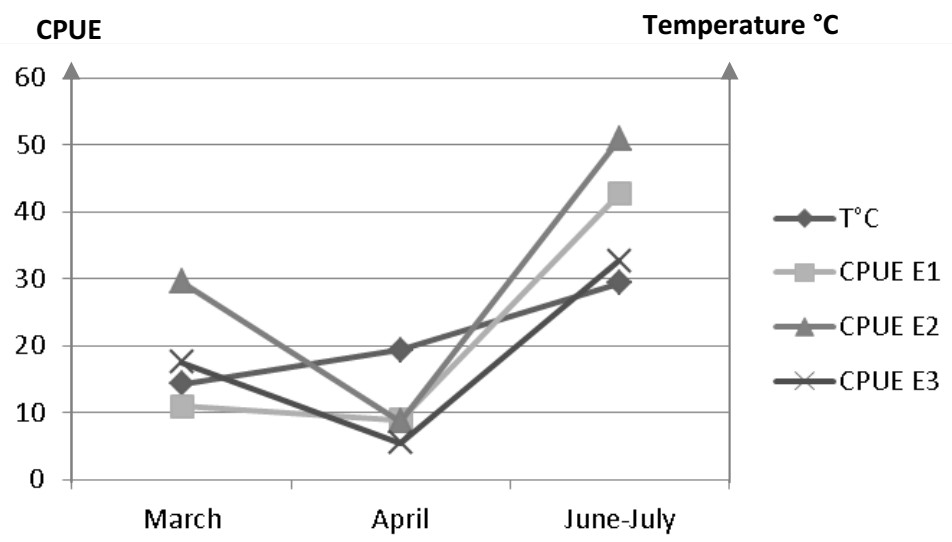

\section{Figure 6}

Mean surface water temperature $\left(T{ }^{\circ} \mathrm{C}\right)$ and mean CPUE in fish-ponds. $(E 1=$ fish-pond $1, E 2=$ fishpond 2, E3 = fish-pond 3).

sessions (Figure 6, CPUE). The number of crayfish captured decreased despite the increase in trapping effort (trap density from 1 to $1.5 \mathrm{ha}^{-1}$ ).

Several berried females were captured during session 1 (March), but only one during session 2 (April). In France, P. clarkii is considered to reproduce from June to September, except in southwestern France where it reproduces from May to December (Nepveu, 2002; Baldry, 2007).

Few juveniles (defined as $<6 \mathrm{~cm}$ of lenght), were captured during all sessions and in all sites. Cohort analysis (Figures 3-5) shows that juveniles were present mostly during session 3 and in small frequencies (3\%). As said above, this result may be biased by the larvae passing through the mesh of the traps. Capture probability $(p C)$ was not sufficiently high in all sessions. For fish-pond 1, $p C$ was low but constant. The lowest $p C$ was obtained for fish-pond 3 during session 2 (less than 1\%): this fish-pond is used for angling and the bait used by fishermen may attract crayfish, being thus a possible source of disturbance. 
Cohorts of individuals can differ, depending on either session or fish-pond (Tables IV-VI) These differences may explain the different estimates of numbers that were most relevant at sessions 1 and 3. Sex ratio differed between fish-ponds, as a probable function of sampling periods. A study conducted in an Italian lake (Dörr et al., 2006) revealed changes in P. clarkii's sex ratio over 11 months of observation. In April, they found that sex ratio was in favor of females, in contrast to the results of our study in which sex ratio was most often in favor of males. However, a sex ratio biased towards males was seen in June-July. Scalici et al. (2010) discussed the difficulties encountered in explaining such variability in sex ratio, as reproduction, incubation, burrowing and recruitment could all differ among introduced populations (Scalici and Gherardi, 2007; Ligas, 2008). Similarly, Ligas (2008) observed that in southern Tuscany the sex ratio of a $P$. clarkii population was extremely variable both geographically and seasonally. We have seen that sex ratio varies among fish-ponds in the same period and among periods in the same fish-pond. Besides, our study has shown that each fish-pond has its peculiarities. It is therefore necessary that trapping should be made several times at different seasons and different sites.

To conclude, trapping effort was not suitable in all the fish-ponds here analyzed, particularly in the case of the larger fish-ponds. Nevertheless this study adds some interesting results demonstrating the plasticity of $P$. clarkii. If trapping effort were to be increased, the protocol would be more suited to small fish-ponds (surface water $<2 \mathrm{ha}$ ), while in large fish-ponds it may be necessary to increase considerably the numbers of traps, with concomitantly increased problems in monitoring.

\section{ACKNOWLEDGEMENTS}

We thank the whole team of the "Parc naturel régional de la Brenne" and especially the Park officers for their help during our field investigation. Thanks are also due to the staff of "Réserve Naturelle Nationale de Chérine" and particularly to Zoey Owen-Jones for giving advice concerning the MARK software. We are indebted to Julian D. Reynolds for his helpful suggestions towards improvement of this paper.

\section{REFERENCES}

Acosta C.A. and Perry S.A., 2000. Effective sampling area: a quantitative method for sampling crayfish populations in freshwater marshes. Crustaceana, 3, 425-431.

Baldry D., 2007. Étude de l'écrevisse américaine Orconectes limosus (Rafinesque, 1817) dans l'étang de Cessy, Pays de Gex, 01170 (France), Le cycle reproductif d'O. limosus, Amicale des pêcheurs de l'étang de Cessy, $14 \mathrm{p}$.

Bellanger J., 2007. Cahier des charges standard pour l'étude méthodologique des populations d'écrevisses autochtones en Rhônes-Alpes, Diagnostic du milieu et des populations d'écrevisses à pieds blancs, Recherche du déterminisme de répartition et des causes de régression, Comité des Fédérations de pêche Rhônes-Alpes, 23 p.

Bourgault P., 2008. Techniques de capture et de marquage des micromammifères, T.P. d'écologie (ECL 307) : volet écologie animale, $10 \mathrm{p}$.

Collas M., Julien C. and Monnier D., 2007. Note technique de la situation des écrevisses en France résultants des enquêtes nationales réalisées entre 1977 et 2006 par le Conseil Supérieur de la Pêche. Bull. Fr. Pêche Piscic., 386, 1-38.

Da Silva H.L.M. and Bueno S.L. de S., 2005. Population size estimation of the exotic crayfish Procambarus clarkii (Girard) (Crustacea, Decapoda, Cambaridae) in the Alfredo Volpi City Park, São Paulo, Brazil. Rev. Bras. Zool. [online], 22, 93-98.

Dörr A.J.M., La Porta G., Pedicillo G. and Lorenzoni M., 2006. Biology of Procambarus clarkii (Girard, 1852) in Lake Trasimeno. Bull. Fr. Pêche. Piscic., 380-381, 1155-1168.

Edgerton B.E., Henttonen P., Jussila J., Mannonen A., Paasonen P., Taugbøl T., Edsman L. and SoutyGrosset C., 2004. Understanding the causes of disease in European freshwater crayfish. Conserv. Biol., 18, 1466-1473. 
Geiger W., Alcorlo P., Baltanas A. and Montes C., 2005. Impact of an introduced Crustacean on the trophic webs of Mediterranean wetlands. Biol. Invasions, 7, 49-73.

Gherardi F., 2006. Crayfish invading Europe: the case study of Procambarus clarkii. Mar. Freshw. Behav. Physiol., 39, 175-191.

Gherardi F., 2007. Understanding the impact of invasive crayfish. In: Gherardi F. (ed.), Biological invaders in inland waters: profiles, distribution and threats, Invading Nature: Springer Series in Invasion Ecology, Springer, Dordrecht, The Netherlands, 507-542.

Gherardi F. and Acquistapace P., 2007. Invasive crayfish in Europe: the impact of Procambarus clarkii on the littoral community of a Mediterranean lake. Freshw. Biol., 52, 1249-1259.

Habsburgo-Lorena A.S., 1979. Present situation of exotic species of crayfish introduced into Spanish continental waters. Freshw. Crayfish., 4, 175-84.

Hobbs H.H., 1989. An illustrated checklist of the American crayfishes (Decapoda: Astacidae, Cambaridae, Parastacidae). Smithson. Contrib. Zool. 480, 1-236.

Holdich D.M., Reynolds J.D., Souty-Grosset C. and Sibley P.J., 2009. A review of the ever increasing threat to European crayfish from non-indigenous crayfish species. Knowl. Managt. Aquatic Ecosyst. 11, 394-395.

Koller N. and Ursenbacher S., 1996. Étude et estimation de l'effectif de Couleuvres vipérines (Natrix maura) et de Couleuvres tesselées (N. tessellata) dans le Lavaux, Université de Lausanne, Faculté des sciences: Institut de zoologie et d'écologie animale, Travail de Certificat, 33 p.

Krebs C.J., 1999. Ecological Methodology, 2nd ed., Benjamin Cummings, Menlo Park, California, 620 p.

Ligas A., 2008. Population dynamics of Procambarus clarkii (Girard, 1852) (Decapoda, Astacidea, Cambaridae) from southern Tuscany (Italy). Crustaceana, 81, 601-609.

Lodge D.M., Taylor C.A., Holdich D.M. and Skurdal J., 2000. Nonindigenous crayfishes threaten North American freshwater biodiversity: Lessons from Europe. Fisheries, 25, 7-20.

Maguire I., Hudina S. and Erben R., 2004. Estimation of noble crayfish (Astacus astacus L.) population size in the velika Paklenica stream (Croatia). Bull. Fr. Pêche. Piscic., 372-373, 353-366.

Nepveu C., 2002. Jeu de fiches descriptives des espèces animales exotiques et indigènes susceptibles de proliférer dans le bassin Artois-Picardie : Procambarus clarkii, Diplôme d'Études Supérieures Spécialisées, Gestion des Ressources Naturelles Renouvelables, 7 p.

Nowicki P., Tirelli T., Mussat Sartor R., Bona F. and Pessani D., 2008. Monitoring crayfish using a mark-recapture method: potentials, recommendations and limitations. Biodivers. Conserv., 17, 3513-3530.

Pellet J. and Pellet B., 2003. Estimation de l'effectif d'une population isolée de salamandres tachetées (Salamandra salamandra) par une approche bayesienne. Bull. Soc. Vaud. Sc. Nat., 88, 483-492.

Rodríguez C.F., Bécares E. and Fernández-Aláez M., 2003. Shift from clear to turbid phase in Lake Chozas (NWSpain) due to the introduction of American red swamp crayfish (Procambarus clarkii). Hydrobiologia, 506-509, 421-426.

Rodríguez C.F., Bécares E., Fernández-Aláez M. and Fernández-Aláez C., 2005. Loss of diversity and degradation of wetlands as a result of introducing exotic crayfish. Biol. Invasions, 7, 75-85.

Scalici M. and Gherardi F., 2007. Structure and dynamics of an invasive population of the red swamp crayfish (Procambarus clarkii) in a Mediterranean wetland. Hydrobiologia, 583, 309-319.

Scalici M., Chiesa S., Scuderi S., Celauro D. and Gibertini G., 2010 Population structure and dynamics of Procambarus clarkii (Girard, 1852) in a Mediterranean brackish wetland (Central Italy). Biol. Invasions, 12, 1415-1425.

Somers K.M. and Stechey D.M., 1986. Variable trappability of crayfish associated with bait type, water temperature and moon phase. Am. Midl. Nat., 116, 36-44.

Souty-Grosset C., 2009. Synthèse des connaissances scientifiques sur les écrevisses exotiques en Europe, Faire face à Procambarus clarkii et aux écrevisses invasives, Aestuaria, $144 \mathrm{p}$.

Strayer D.L., 2010. Alien species in fresh waters: ecological effects, interactions with other stressors, and prospects for the future. Freshw. Biol., 55 (Suppl. 1), 152-174.

White G.C. and Burnham K.P., 1999. Program MARK: survival estimation from populations of marked animals. Bird Study, 46 (Suppl.), 120-138. 